\title{
Sheep and goat farming in Imo state Southeast Nigeria: A traditional vocation at the
} verge of extinction?

${ }^{1}$ Anyanwu, N. J., ${ }^{1}$ Ogualu, J. O., ${ }^{1}$ Odoemelam, V. U., ${ }^{3}$ Kalio, G. A. and ${ }^{2}$ Ekpe, I. I.

${ }^{\prime}$ Department of Animal Science and Technology, Federal University of Technology, Owerri

${ }^{2}$ Department of soil science, Federal University of Technology, Owerri

${ }^{3}$ Department of Agric. Science, Ignatius Njuru University of Education,

Abstract

Port Harcourt

Since prehistoric times, sheep and goat farming has been an integral part of the farming system of the people of South east Nigeria. This study investigated the current state of sheep and goat farming amongst households in Imo State south eastern Nigeria. A total of one hundred and fifty (150) structured questionnaires were distributed to farmers randomly selected from three Local Government Areas (LGAs) in Imo state namely, Oru West, Ahiazu Mbaise and Ezinihitte Mbaise to determine the socio-economic characteristics, production systems, breeding and reproduction, constraints and strategies for economic improvement in a focus group interview. Only 89 farmers were available for interview. The results revealed significant decline in sheep and goat farming amongst the households across four generations within the households interviewed. Lack of interest due to poor policy framework, low productivity of existing breeds, difficulty in feed supply and high cost of breeding stock was identified as constraints of sheep and goat production in thiese areas. It was also observed that older people were more directly involved in sheep and goat farming than youths. 59.6\% of the farmers were females, and 31-50\% of the farmers were between the ages of 31 and 50 years. Farming was the most common occupation amongst the households while trading was the next. Results also showed that $76.4 \%$ of the communities had history of sheep and goat keeping whereas 73\% of the total families interviewed had a history of sheep and goat keeping. It was also observed that 33.7\% of households were involved in poultry enterprise and 25.3\% involved in fish farming. Only $4.8 \%$ engaged in sheep and goat farming. Results obtained also revealed that $48.3 \%$ of the identified sheep and goat farmers kept breeds of sheep and goat from northern Nigeria while 40.4\% maintained the west African dwarf breed. 34\% of respondents believed that access to grants and credit facilities, $25 \%$ believed provision of land in urban areas, while $21 \%$ believed improvement in small ruminant feed technology, would improve production. Lambing and kidding was mostly twice a year (48.3\%). Breeding was mostly observed to be uncontrolled (51.7\%). Also, the results showed that, 59.6\% of the farmers were willing to pay for veterinary services. The most important diseases within these areas were worms, ecto-parasites and peste des petits ruminants (PPR). It can be inferred from the study that farmers within the region appear to pay greater emphasis on poultry production and fish farming to the detriment of smallholder sheep and goat farming which could be attributed to poor knowledge of sheep and goat farming technologies resulting to low productivity.

Keywords: sheep and goat farming, south eastern Nigeria, West African dwarf breed, extension services

\section{Imtroduction}

Sheep and goats represent the predominant ruminant animals in South eastern Nigeria and the West African dwarf breed is indigenous to this area. In terms of contribution to house hold meat supply by aggregate demand, goat meat is second to beef followed by poultry (Aborishade and 


\section{Sheep and goat farming in Imo state Southeast Nigeria}

Carpio, 2017). Regrettably, over 90\% of animals slaughtered within the region are supplied from northern Nigeria (Francis, 1990). In fact, the West African dwarf breed of sheep and goat just like the West African dwarf cattle, is on the verge of extinction. The West African dwarf breed of sheep and goats are adapted to the humid rainforest zone, along the Atlantic coast, which stretches from Nigeria to Cameroun, Congo to the east, Benin, Togo, Ghana, Liberia up to the Fouta Djallon highlands of the Gambia (Williamson and Payne, 1978). They are typano-tolerant and represent an important component of the crop-livestock farming system of the indigenous population. Besides provision of food, they act as a reserve of wealth, a living bank, a source of income, employment, manure, raw material and part of the social and customary ceremonies. Their size and adaptability and short generation interval make them the most preferred among domestic animals and makes for easy management among women and children. The short generation interval makes them easier to replenish stocks after disease outbreak. It is also a form of insurance against crop failure. Despite these advantages, an important vocation for small holder farmers, is at a danger of extinction. Sheep and goat production is largely concentrated in the hands of small holders who apply little if any, modern techniques required to meet the demand of meat in a fast changing world where technology holds sway. Ownership of small sheep and goats is regarded as an investment since they could be sold to meet compelling family needs and obligations, slaughtered for consumption at home or at festivals. In addition, very little capital investment is required in buildings, maintenance and upkeep and purchase of stock since families could receive initial breeding stock as a gift or tied to joint sharing of offspring. Currently, there are four identified production systems. Subsistence system which is characterized by a small number of holding often less than 5. They are kept in stalls, tethered or allowed to roam about. There is sometimes absence of housing and animals co-habit within the farmers compound on corridors, open kitchen or halls. Sometimes animal's shelter is erected adjacent to the farmers wall or fence. Animals scavenge around the neighborhood unaccompanied, throughout the day searching for feed and water but returns to the owner's home in the evening. They are prone to predators and theft, accidental death by moving vehicles. Extensive system allows the animals to graze and browse large areas of marginal land usually unsuitable for cultivation under the care of a herder. However, this system has given rise to frequent resource conflicts between crop farming communities and migrant herders within the southern parts of Nigeria. It is on the grounds of appraising the current state of production and evolving strategies for economic improvement that this study was initiated.

\section{Materials and methods}

The study was conducted in three Local Government Areas (L.G.As) namely; Oru West, Ahiazu Mbaise and Ezinihitte Mbaise. Imo state lies within latitudes $4^{\circ} 45^{\prime} \mathrm{N}$ and $7^{\circ} 15^{\prime} \mathrm{N}$, and longitude $\mathrm{s} 6^{\circ} 50^{\prime} \mathrm{E}$ and $7^{\circ} 25^{\prime} \mathrm{E}$ with an area of about $5,100 \mathrm{sq} \mathrm{km}$ (Wikipedia,). Oru West lies within latitude $5.37^{\circ} \mathrm{N}$ and longitude $6.57^{\circ} \mathrm{E}$. It has an area of $93 \mathrm{~km} 2$ (36 sq mi) and a population of 117,492 (NPC, 2006). Ahiazu Mbaise is situated within latitude $5^{\circ} 32^{\prime} 55.259^{\prime \prime} \mathrm{N}$ and $7^{\circ} 16^{\prime} 8.364^{\prime \prime} \mathrm{E}$. It has an area of $114 \mathrm{~km}^{2}$ and a population of 170,902 (NPC, 2006). Ezinihitte Mbaise lies between latitude $5^{\circ}$ $28^{\prime} 43.5^{\prime \prime}\left(5.4788^{\circ}\right)$ North and longitude $7^{\circ}$ $19^{\prime} 34.5^{\prime \prime}\left(7.3263^{\circ}\right)$ East. The study was conducted with the aid of structured questionnaires, using focus group and personal interviews and observations 


\section{Anyanwu, Ogualu, Odoemelam, Kalio and Ekpe}

within the different communities of the three Local Government Areas (LGAs). The communities were selected using a stratified random sampling and thirty respondents were interviewed in Ahiazu and Ezinihitte Mbaise and twenty-nine in Oru West making up a total of eighty-nine (89) respondents overall.

\section{Results and discussions}

The results indicated that $71.9 \%$ of respondents were rural dwellers, 20.2\% peri-urban dwellers and 7.9\% urban dwellers showing that the study area was majorly rural. The respondents were within the ages of 21 to over 70 years. While $42.7 \%$ were between the ages of 31-50 years, $37.1 \%$ were between the ages of 21-30 and $15.7 \%$ were between the ages of $51-70$ while $4.5 \%$ were above 70 years. Results also indicated that there were more females $(59.6 \%)$ than males $(40.4 \%)$ as shown in Table $1.56 .2 \%$ of respondents were married and $43.8 \%$ were single. This may indicate that married couples consider sheep and goat farming as an important source of food and economic security although current production methods may not be attractive to the youths, a development which can be addressed by providing the enabling environment for youths to go into commercial sheep and goat production (Anyanwu et. al., 2010). The educational status of the respondents showed that $32.6 \%$ had secondary education while $31.5 \%$ had tertiary education. About $16.9 \%$ had primary education while $19.1 \%$ had no formal education. We can report from this result that most of the respondents were educated. Access to education is related to the capacity of respondents especially women, to use appropriate information and skills for enterprise development and generation (Adeleye et al., 2016). Most of the respondents $(51.7 \%)$ had household size of between 5 and 10; while $13.7 \%$ of the respondents had household size of 11 and
15. It was also recorded that the primary occupation of most of the respondents (49.4\%) was farming, $19.1 \%$ were involved in trading, $13.5 \%$ were civil servants, while $7.9 \%$ were students and businessmen, respectively. Furthermore, 53.9\% reported farming as secondary occupation, $30.3 \%$ as trading. It was also recorded from the study that $84.3 \%$ of the total respondents were engaged in agriculture whereas $15.7 \%$ were not. This is in agreement with previous reports that agriculture is the major source of livelihood for the rural people in developing countries (FAO, 2008).

\section{Production systems and choice of enterprises}

An analysis of the data revealed that $33.7 \%$ of the respondents preferred poultry as livestock enterprise of choice, $25.3 \%$ fish farming, $18.1 \%$ piggery and /marketing respectively while a very small number of respondents $(4.8 \%)$ indicated sheep and goat as a livestock enterprise of choice. This agreed with the previous report by Okoli et al. (2004) that poultry business enterprise in Imo state, Nigeria is attractive and an enterprise of choice where practitioners are willing to continue in throughout their lifetime. Again, 33.7\% of the respondents affirmed that they would venture into crop farming if given a startup capital, 25.3\% declared marketing of agricultural products as a choice enterprise, $18.1 \%$ also chose fishery and others respectively. Whereas a little number of them $(4.8 \%)$ chose livestock as a choice of enterprise upon having access to loan. It was also recorded that $76.4 \%$ of the respondents indicated that their communities had a history of sheep and goat farming while $73 \%$ of the households had a family history of sheep and goat keeping. The practice of sheep and goat keeping along the successive generations declined from $48 \%$ among the great grandparents, $22 \%$ for grandparents, $17 \%$ for parents to $11 \%$ for the respective respondent. The major reason for sharp 


\section{Sheep and goat farming in Imo state Southeast Nigeria}

decline in sheep and goat production among the respondents (30.3\%) was lack of interest. Other reasons for sharp decline in sheep and goat production (14.6\%) was low productivity of existing breeds. $10.1 \%$ recorded that lack of innovation in production system and high cost of breeding stock was the major reason for the sharp decline, respectively while incidence of pest and diseases was 7.9\% while 5.6\% indicated drudgery and high labour involvement. From the above results, it can be reported that low productivity of the existing breeds or sheep and goat and lack of innovation in production system resulted to lack of interest and perhaps the major reasons for sharp decline in sheep and goat production in the study area. About $40.35 \%$ of the respondents practiced subsistence system of sheep and goat production while $37.1 \%$ practiced intensive system, $16.9 \%$ also practiced extensive system and 5.6\% also practiced semi-intensive system. This is contrary to the report from Northern Nigeria that small ruminants were mostly managed under extensive system (Ajala and Gefu,2003). The subsistence system confirmed that small ruminants are not kept in commercial sizes and are actually kept to augment family income especially in South eastern Nigeria. The above results are represented in Table 2 below.

Table 1: Socio-economic characteristics of sheep and goat farmers within the study area

\begin{tabular}{|c|c|c|c|}
\hline Parameters & Class & Frequency & Percentage \\
\hline \multirow[t]{4}{*}{ LGA } & Oru west & 29 & 32.6 \\
\hline & Ahiazu Mbaise & 29 & 32.6 \\
\hline & Ezinihitte & 31 & 34.8 \\
\hline & Total & 89 & 100.0 \\
\hline \multirow[t]{4}{*}{ Locality } & Urban & 7 & 7.9 \\
\hline & Peri-urban & 18 & 20.2 \\
\hline & Rural & 64 & 71.9 \\
\hline & Total & 89 & 100.0 \\
\hline \multirow[t]{5}{*}{ Age } & $21-30$ & 33 & 37.1 \\
\hline & $31-50$ & 38 & 42.7 \\
\hline & $51-70$ & 14 & 15.7 \\
\hline & Above 70 & 4 & 4.5 \\
\hline & Total & 89 & 100.0 \\
\hline \multirow[t]{3}{*}{ Sex } & Male & 36 & 40.4 \\
\hline & Female & 53 & 59.6 \\
\hline & Total & 89 & 100.0 \\
\hline \multirow[t]{3}{*}{ Marital Status } & Single & 39 & 43.8 \\
\hline & Married & 50 & 56.2 \\
\hline & Total & 89 & 100.0 \\
\hline \multirow[t]{5}{*}{ Level of education } & None & 17 & 19.1 \\
\hline & Primary & 15 & 16.9 \\
\hline & Secondary & 29 & 32.6 \\
\hline & Tertiary & 28 & 31.5 \\
\hline & Total & 89 & 100.0 \\
\hline \multirow[t]{4}{*}{ Household size } & 2 & 1 & 1.1 \\
\hline & 3 & 2 & 2.2 \\
\hline & 4 & 6 & 6.7 \\
\hline & 5 & 8 & 9.0 \\
\hline
\end{tabular}


Anyanwu, Ogualu, Odoemelam, Kalio and Ekpe

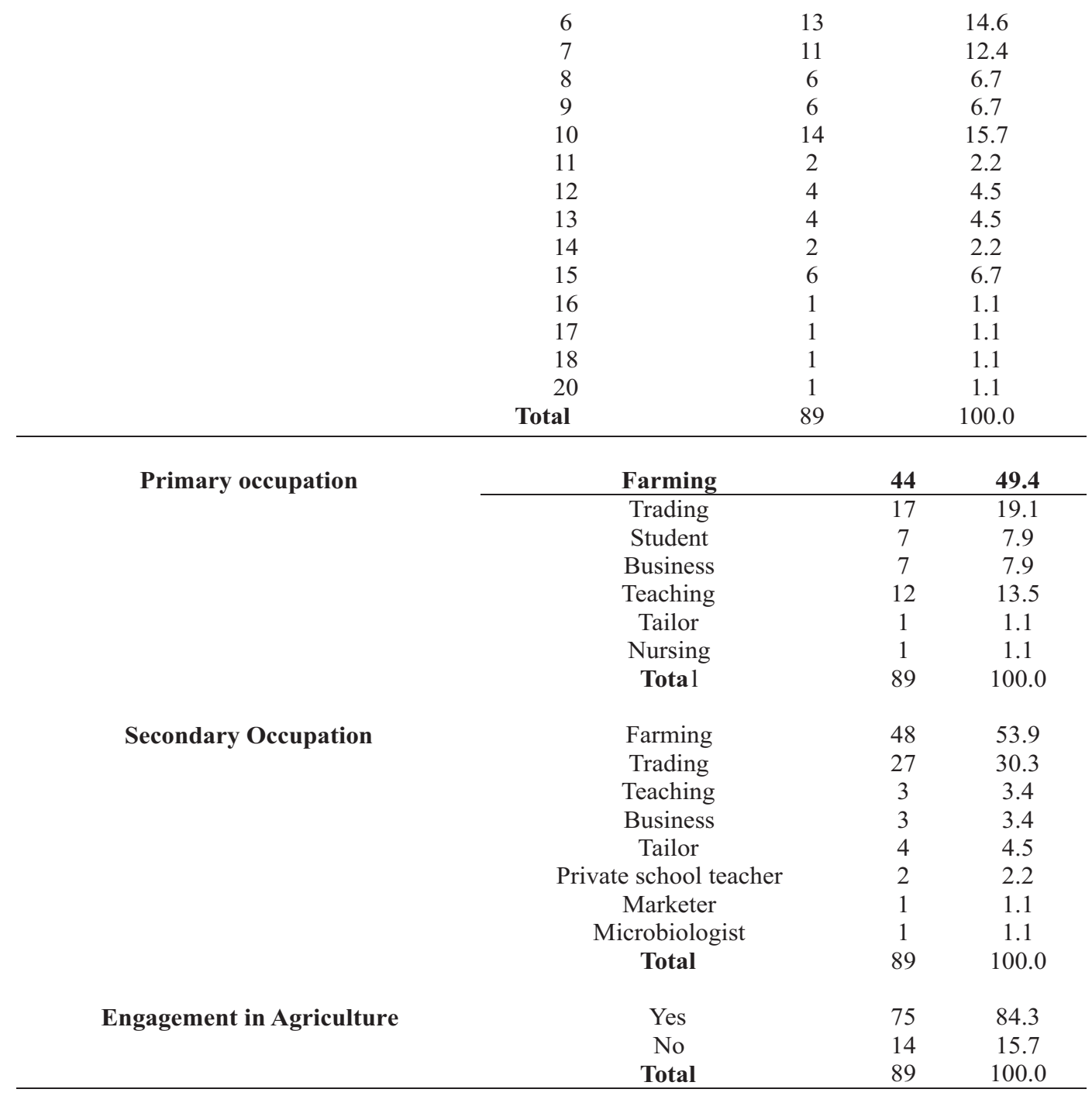

Strategies for economic improvement of sheep and goat farming within the syudy area

The most workable solution to revamp sheep and goat production as consented by the respondents $(33.7 \%)$ was the advancement of credit facilities. Other workable solutions to revamp sheep and goat production in order of importance were the provision of land by government in peri-urban centres for cluster sheep and goat farming (24.7\%), improvement in ruminant feed technology $(21.3 \%)$, establishment of planted fodder banks $(12.4 \%)$ and innovation in housing and feeding systems. So, presumably, advancement of credit facilities such as loan or grant to the farmers can be a good workable solution to revamping sheep and goat production in the study area. This can be augmented by government providing land in peri-urban centres for cluster sheep and goat as well as the improvement in ruminant feed technologies. The reports given by the respondents $(59.1 \%)$ showed 


\section{Sheep and goat farming in Imo state Southeast Nigeria}

that the total annual income generated from agricultural enterprise per year was below $<120,000$ which was below the current minimum wage of public sector workers. Furthermore, $30.7 \%$ earned between $<121,000$ to $<240,000$ while $6.8 \%$ reported earnings between $<481,000$ to $<1,000,000$. This low income reported by these households could be the reason for the declining interest in sheep and goat farming. This could be explained by subsistence production system prevalent in the study area probably due to lack of capital and appropriate technologies to commercialize aspects of the enterprise value chain. $25.8 \%$ of the respondents affirmed that delivery of new research technologies to target farmers can best enhance sheep and production in the study area. Furthermore, $24.7 \%$ consented that technology can enhance sheep and goat production in the study area through improvement in genetic potential. $14.6 \%$ of the respondents reported that access to marketing information by linking farmers with consumers using cell phones can be useful in the technological enhancement of sheep and goat production in the study area. Also, $11.2 \%$ affirmed that use of ready-made packaged feeds and modified housing for urban and peri-urban producers can be another innovation to enhancing sheep and goat production in the study area respectively. In addition, only $9.0 \%$ reported that oestrus synchronisation can be used to enhance production. Overall, majority of respondents $(60 \%)$, agreed that deployment of new technologies holds the key to economic improvement.

\section{Breeding and reproduction of sheep and goats within the study area}

Results obtained from the respondents showed that $48.3 \%$ kept Northern breeds of sheep and goat, $40.4 \%$ kept West African dwarf and only a few number (11\%) kept other breeds. This was supported by previous reports that most sheep and goats consumed or kept in the south are introduced from the northern parts of Nigeria (Francis, 1990). Also from above results, we can support the claims that West Africa dwarf sheep and goat are found in the whole area of south Latitude $14^{\circ} \mathrm{N}$ and humid forest belts of the south (Chukwuma, 2018). Results also revealed that $51.7 \%$ of the respondents practiced uncontrolled breeding while $42.7 \%$ also practiced controlled breeding. In terms of number of kidding/lambing per year, $48.3 \%$ reported twice per year, $29.2 \%$ had twice in three years, while $22.4 \%$ reported once per year. Furthermore, on the number of offsprings per litter, $42.7 \%$ reported twins, $32.6 \%$ triplets while $13.5 \%$ reported single births while a small fraction $11.2 \%$, reported four kids/lambs at a single birth. This goes to confirm the claims in literature that the West African dwarf goats are prolific and a characterized by multiple births, hence are capable of increasing the size of the individual farmers holding within a very short time. On the prevalence of diseases, respondents reported that $43.8 \%$ had worms and emaciation, $32.6 \%$ had mange and other ecto-parasites and $19.1 \%$ had peste des petits ruminants (PPR). This present report has shown that worms and emaciation, mange and ecto-parasites as most common more than PPR. This varies with previous report by Okoli et al. (2003), that PPR, trypanosomosis and bronchopneumonia were the important diseases of WAD goats and sheep in Imo State, Nigeria.About 59.6 of the respondents were willing to pay for the services of professional veterinary practitioners for their sheep and goats. This was in agreement with claims by Ahuja and Sen (2006) that farmers exhibit significant willingness to pay for animal health services even in very poor areas. Furthermore, about 60.7 \%of the 
Anyanwu, Ogualu, Odoemelam, Kalio and Ekpe

Table 2: Production systems of sheep and goat farming within the study area

\begin{tabular}{|c|c|c|c|}
\hline Parameters & Class & Frequency & Percentage \\
\hline \multirow[t]{6}{*}{ Access to Loan } & Crop farming & 24 & 33.7 \\
\hline & Livestock & 25 & 4.8 \\
\hline & Fishery & 10 & 18.1 \\
\hline & Marketing of agri-products & 23 & 25.3 \\
\hline & Others & 4 & 18.1 \\
\hline & Total & 86 & 100.0 \\
\hline \multirow[t]{6}{*}{ Farming Enterprise } & Poultry & 28 & 33.7 \\
\hline & Sheep and goat & 4 & 4.8 \\
\hline & Piggery & 15 & 18.1 \\
\hline & Fish farming & 21 & 25.3 \\
\hline & Trading/marketing in livestock & 15 & 18.1 \\
\hline & Total & 83 & 100.0 \\
\hline \multirow[t]{3}{*}{ Community History Of Goat Keeping } & Yes & 68 & 76.4 \\
\hline & No & 21 & 23.6 \\
\hline & Total & 89 & 100.0 \\
\hline \multirow[t]{3}{*}{ Family History Of Goat Keeping } & Yes & 65 & 73.0 \\
\hline & No & 24 & 27.0 \\
\hline & Total & 89 & 100.0 \\
\hline \multirow{5}{*}{$\begin{array}{c}\text { Generational history of sheep and goat } \\
\text { keeping }\end{array}$} & Great grandfather & 33 & 48.5 \\
\hline & Grand father & 15 & 22.1 \\
\hline & Father & 12 & 17.6 \\
\hline & Self & 8 & 11.8 \\
\hline & Total & 68 & 100.0 \\
\hline \multirow{11}{*}{$\begin{array}{c}\text { Reason For Sharp Decline In Sheep And } \\
\text { Goat Production }\end{array}$} & Urbanisation making access & 10 & 11.2 \\
\hline & Poor research and extension & 6 & 6.7 \\
\hline & $\begin{array}{c}\text { Low productivity of existing } \\
\text { breeds }\end{array}$ & 13 & 14.6 \\
\hline & $\begin{array}{l}\text { Drudgery and high labour } \\
\text { requirement }\end{array}$ & 5 & 5.6 \\
\hline & Incidence of pest and disease & 7 & 7.9 \\
\hline & Lack of innovation & 9 & 10.1 \\
\hline & Lack of interest & 27 & 30.3 \\
\hline & High cost breeding stock & 9 & 10.1 \\
\hline & Others & 3 & 3.4 \\
\hline & Total & 89 & 100.0 \\
\hline & Subsistence & 36 & 40.3 \\
\hline \multirow[t]{4}{*}{ Management System } & Intensive & 33 & 37.1 \\
\hline & Extensive & 15 & 16.9 \\
\hline & Semi-intensive & 5 & 5.6 \\
\hline & Total & 89 & 100.0 \\
\hline
\end{tabular}

respondents kept the animals as a business to augment family income, while $19.1 \%$ reported keeping the animals for subsistence purposes and out of passion. This report is in agreement with previous reports that small ruminants served as an investment and source of revenue to augment family income (Ayoola and Ayoade, 1992). 


\section{Sheep and goat farming in Imo state Southeast Nigeria}

Table 3: Strategies for economic improvements of sheep and goat farming within the study area

\begin{tabular}{cccc}
\hline Parameters & Class & Frequency & Percentage \\
\hline Workable Solution To Revamp & Providing planted fodder bank & 11 & 12.4 \\
Sheep And Goat Production & Improvement in ruminant feed technology & 19 & 21.3 \\
& Govt. Providing land in per-urban centres & 22 & 24.7 \\
& Innovation in housing and feeding system & 5 & 5.6 \\
& Advancement of credit facilities & 30 & 33.7 \\
Total Annual Income From & Others & 2 & 2.2 \\
Year & Total & 89 & 100.0 \\
Agricultural Enterprise Per & $<\mathrm{N} \mathrm{120,000}$ & 52 & 59.1 \\
& N 121,000 - n 240,000 & 27 & 30.7 \\
Nechnology Use To Enhance & N 481,000 - n 1,000,000 & 2 & 2.3 \\
Sheep and Goat Production & N 1,000,000 & 6 & 6.8 \\
& Total & 1 & 1.1 \\
& Delivery of new research technologies & 23 & 100.0 \\
& Improvement in genetic potential & 22 & 25.8 \\
& Access to marketing information by linking & 13 & 24.7 \\
& farmers with consumers using cell phones & & 14.6 \\
& Oestrus synchronisation & 8 & 9.0 \\
& Use of ready-made packaged feeeds & 10 & 11.2 \\
& Modified housing for urban and peri-urban & 10 & 11.2
\end{tabular}

Table 4: Breeding and reproduction of sheep and goats within the study area

\begin{tabular}{|c|c|c|c|}
\hline Parameters & Class & Frequency & Percentage \\
\hline \multirow[t]{4}{*}{ Breed Of Sheep and Goat Kept } & West African dwarf & 36 & 40.4 \\
\hline & Northern breeds & 43 & 48.3 \\
\hline & Others & 10 & 11.2 \\
\hline & Total & 89 & 100.0 \\
\hline \multirow[t]{4}{*}{ Type Breeding Practiced } & Controlled breeding & 38 & 42.7 \\
\hline & Uncontrolled breeding & 46 & 51.7 \\
\hline & Other & 5 & 5.6 \\
\hline & Total & 89 & 100.0 \\
\hline \multirow[t]{4}{*}{ Number Of Kidding/Lambing (Birth) Per Years } & Once & 20 & 22.4 \\
\hline & Twice & 43 & 48.3 \\
\hline & Twice in three years & 26 & 29.2 \\
\hline & Total & 89 & 100.0 \\
\hline \multirow{5}{*}{ Number Of Offspring Per Litter } & One & 12 & 13.5 \\
\hline & Two & 38 & 42.7 \\
\hline & Three & 29 & 32.6 \\
\hline & Four & 10 & 11.2 \\
\hline & Total & 89 & 100.0 \\
\hline \multirow[t]{5}{*}{ Major Disease Challenge } & PPR & 17 & 19.1 \\
\hline & Mange and ecto-parasites & 29 & 32.6 \\
\hline & Worms and emaciation & 39 & 43.8 \\
\hline & Others & 4 & 4.5 \\
\hline & Total & 89 & 100.0 \\
\hline \multirow[t]{3}{*}{ Willingness To Pay For The Services } & Yes & 53 & 59.6 \\
\hline & No & 36 & 40.4 \\
\hline & Total & 89 & 100.0 \\
\hline \multirow[t]{5}{*}{ Major Reason For Keeping The Farm Animals } & For subsistence & 17 & 19.1 \\
\hline & As a business & 54 & 60.7 \\
\hline & Passion and interest & 17 & 19.1 \\
\hline & Others & 1 & 1.1 \\
\hline & Total & 89 & 100.0 \\
\hline
\end{tabular}




\section{Conclusion}

From the results of this study, it can be concluded that the major constraints of sheep and goat production in the study area were lack of interest and this could be attributed to the low productivity of existing breeds, low income derived from the enterprise relative to other farm enterprises and absence of technological innovations in feeding and management systems. In addition, lack of innovation in production system and high cost of breeding stock were also contributing factors. It was also inferred that most breed of sheep and goat in the study area were mainly the northern breeds. The preference for the Savanna breeds of goats might be influenced by its larger size relative to the indigenous breeds. The fact that older people are more directly involved in the small ruminant production system than the youths could be improved by the incorporation of new technologies that reduce drudgery. Appropriate measures should be ensured by the government to motivate the youths to participate in the activities of sheep and goat production. The use of pelletized forage feeds can reduce the problem of feeding if the technology is adopted.

\section{References}

Aborisade, O. and Carpio, C. E. 2017. Household Demand for Meat in Nigeria. Selected Paper prepared for presentation at the Southern Agricultural Economics Association's 2017 Annual Meeting, Mobile Alabama, February, 4-7 2017

Francis, P. A. 1990. Small Ruminant Marketing in Southwest Nigerian 1990. Agric. Econ., 4: 193-208. International Livestock Centre for A fri c a, $\mathrm{H} \mathrm{u} \mathrm{mid} \mathrm{Z}$ on e Programme,PMB 5320, Ibadan, Nigeria.
Adeleye, O., Alli-Balogun, J. K., Afiemo, O. G. and Bako S. 2016. Effects of Goat Production on the Livelihood of Women in Igaabi, Chikun and Kajuru Local Government Areas,Kaduna State Asian Journal of Agricultural Extension Economics and Sociology.11(1):1-8, 2016; Article no.AjAEES.22194.

Ahuja, V. and Sen, A. 2006. Willingness to Pay for Veterinary Services: Evidence from Poor Areas in Rural India. Pro-Poor Livestock Policy Initiative, A Living from Livestock. RR Nr. 2006;

Ajala, M. K. and Gefu, J. O. 2003. Socioeconomic factors influencing small ruminants management practices in Kaduna State. Moor Journal of Agriculture Research Vol.4(2) 2003: 274-280.

Anyanwu, N. J., Ohaeri, P. C., Iheshiulor, O. O. M. and Etela, I. 2010. Preliminary investigations into the socio-economic and production characteristics of sheep and goat farming in the Owerri zone of Imo State, Nigeria. Global Research Journals Vol. 1. (1) pp.006 - 009 August 2010.

Ayoola, G. B. and Ayoade, J. A. 1992. Role of women in livestock enterprises in Nigeria. A case study of rural Tiv and Idoma communities in Benue State.

Chukwuma, N. 2018. Breeds of and Breeding of Sheep and Goats. A g r i c u $1 \mathrm{tur}$ a 1 D i a $\mathrm{y}$ (http://agriculturediary .com/breeds-breeding-sheep-goatsmethods/). Coffey, Linda, Margo Hale, and Ann Well; "Goats: Sustainable Production Overview.

FAO 2008. Food and Agriculture Organization of the United Nations. Rural Household and their Pathway out of Poverty in World Development Report 2008. 


\section{Sheep and goat farming in Imo state Southeast Nigeria}

Francis, P. A. 1990. Small Ruminant Marketing in Southwest Nigerian 1990. Agric. Econ., 4: 193-208. International Livestock Centre for Afric, Humid Zone Programme, PMB 5320, Ibadan, Nigeria.

Okoli, I. C., Anyaegbunam, C. N., Etuk, E. B., Uchegbu, M. C. and Udedibie, A. B. I. 2004. Socioeconomic characteristics of poultry business entrepreneurs in Imo State, Nigeria. Journal of agriculture and social research vol. 4, No. 2, 2004.

Okoli, I. C. 2003. Incidence and modulating effects of environmental factors on trypanosomosis, peste des petit ruminants (PPR) and bronchopeneumonia of West African dwarf goats in Imo State, Nigeria. Livestock Research for Rural Development 15 (9) 2003.
SPSS Release 7.0, 1999. Statistical Package for Social Sciences. Procedures and Facilities for Release 7.0. McGraw Hill Book Co. NY

Wikipedia, 2018. Sheep, Retrieved from http://en.wikipedia.org/wiki/Domes tic_sheep\#cite_ref-smith5_13-1

Williamson, G. and Payne, W. J. A. 1978. An Introduction to Animal Husbandry in the Tropics. 4th edition. Tropical Agricultural Sciences, Longman, London and New York.

Received: $29^{\text {th }}$ May, 2020

Accepted: $29^{\text {th }}$ September, 2020 